\title{
STRUCTURAL PROPERTIES OF APATITES FROM FINLAND STUDIED BY FTIR SPECTROSCOPY
}

\author{
MIHKEL VEIDERMA, RENA KNUBOVETS and KAIA TÕNSUAADU
}

\begin{abstract}
VEIDERMA, MIHKEL, KNUBOVETS, RENA and TÕNSUAADU, KAIA 1998. Structural properties of apatites from Finland studied by FTIR spectroscopy. Bulletin of the Geological Society of Finland 70, Parts 1-2, 69-75.

Studies by XRD and FTIR analyses of the structure of Sokli and Siilinjärvi apatites and a comparison with the Kola and Kovdor apatites are presented. In the structure of apatites from Finland the occurrence of F...OH and F...OH...F bonds and the incorporation of $\mathrm{CO}_{3}{ }^{2-}$ ions into $\mathrm{A}$ and $\mathrm{B}$ positions were established.
\end{abstract}

Key words: apatite, hydroxylapatite, chemical composition, crystal structure, bonding, infrared spectra, FTIR spectra, Sokli, Siilinjärvi, Finland.

Mihkel Veiderma, Tallinn Technical University, Tallinn, 19086, Estonia

Rena Knubovets, The Open University of Israel, Ramat Aviv, Tel Aviv 61392,

Israel

Kaia Tõnsuaadu, Tallinn Technical University, Tallinn, 19086, Estonia

\section{INTRODUCTION}

Fluorapatite $\mathrm{Ca}_{10}\left(\mathrm{PO}_{4}\right)_{6} \mathrm{~F}_{2}$ is assumed to be a basic mineral of phosphate rocks. Its crystal structure is hexagonal, symmetry group $\mathrm{P}_{3} / \mathrm{m}$. The actual composition of natural apatites differs from that of the idealized apatite composition. It may include different isomorphous substituents. For magmatic apatites, substitutions on the cationic side and on the hexagonal axis of the apatite crystal are frequent; for sedimentary apatites (phosphorites), besides these, there are also substitutions for $\mathrm{PO}_{4}{ }^{3-}$, particularly by $\mathrm{CO}_{3}{ }^{2-}$. As a result of metamorphism and weathering, the latter type of substitutions may occur also in primarily magmatic apatites.

The composition and structure of apatite from the Kola Peninsula (northwestern Russia) corre- sponds relatively well to ideal fluorapatite. The apatites of other apatite deposits in northern Europe (Kovdor in North Karelia, Russia, Siilinjärvi and Sokli in Finland, and Kiruna in Sweden) represent fluorhydroxyapatites (or fluorhydroxylapatites) $\mathrm{Ca}_{10}\left(\mathrm{PO}_{4}\right)_{6} \mathrm{~F}_{2-\mathrm{n}}(\mathrm{OH})_{\mathrm{n}}$ (Veiderma \& Knubovets 1991, Veiderma et al. 1996). The geological characteristics of the Siilinjärvi and Sokli carbonatite complexes were studied by Puustinen (1971) and Vartiainen (1980), respectively, but up to the present there are no data published on the fine crystal structure of the apatites of these complexes.

A review of the infrared (IR) spectra of hydroxyapatite and the appearence of additional stretching and liberational bands caused by the replacement of $\mathrm{OH}^{-}$ions by $\mathrm{F}^{-}$ions has been given in a monograph by Elliott (1994). The structure 
Table 1. Characteristics of the apatite samples (chemical composition, wt.\%).

\begin{tabular}{lccccc}
\hline & Siilinjärvi & \multicolumn{2}{c}{ Sokli } & Kola & \multirow{2}{*}{ Kovdor } \\
& & primary (a) & weathered (b) & & \\
\hline $\mathrm{P}_{2} \mathrm{O}_{5}$ & 36.4 & 35.4 & 38.7 & 39.6 & 36.5 \\
$\mathrm{CaO}$ & 53.1 & 48.7 & 51.9 & 52.0 & 51.1 \\
$\mathrm{MgO}$ & 1.4 & 4.1 & 1.9 & 0.2 & 2.7 \\
$\mathrm{~F}$ & 2.4 & 1.6 & 1.8 & 3.3 & 1.0 \\
$\mathrm{CO}_{2} \mathrm{CO}_{2}^{*}$ & 4.4 & 4.6 & 3.6 & - & 3.4 \\
$\mathrm{~F}$, atom/mole & 1.1 & 0.9 & 1.6 & - & 0.2 \\
Unit cell parameters, & 1.48 & 1.01 & 1.04 & 1.87 & 0.61 \\
$\mathrm{a}_{0} \pm 0.002$ & 9.402 & 9.390 & 9.388 & 9.384 & 9.403 \\
$\mathrm{c}_{0} \pm 0.005$ & 6.904 & 6.884 & 6.886 & 6.893 & 6.884 \\
Accompanying & calcite & dolomite & dolomite & quartz & calcite \\
minerals & phlogopite & & & & dolomite \\
& & & & forsterite \\
\hline
\end{tabular}

* After treatment by triammonium citrate solution for elimination of carbonates (Silverman et al. 1952).

of biological and synthetic apatites has been studied by Fourier transformation infrared (FTIR) analysis during the past decade by Gadaleta et al. (1996), Penel et al. (1997), Rehman and Bonfield (1997), and Suetsugu et al. (1998) and of natural apatites by Regnier et al. (1994). In the domain $\left(3500-3600 \mathrm{~cm}^{1-}\right)$ of $\mathrm{OH}$ groups stretching mode of fluorhydroxyapatites two bands at 3573 and $3537 \mathrm{~cm}^{-1}$ were observed in FTIR spectra.

The curve-fitting analysis of FTIR spectra that enables to extract more information about the underlying peaks by calculating the height, width, position, etc. is seldomly used. Gadaleta et al. (1996) used this in the domain of $\mathrm{PO}_{4}{ }^{3-}$ ions vibrations at $650-500 \mathrm{~cm}^{-1}$ and $1100-900 \mathrm{~cm}^{-1}$ for evaluation of the subtle spectral changes in hydroxyapatites occurring during the maturation of crystals.

The aim of this work was to study the use of FTIR spectroscopy and curve-fitting analysis of the obtained spectra for determination of the structural properties of apatites from Finland and the comparison of these with the properties of apatites from the Kola and Kovdor deposits.

\section{MATERIALS AND METHODS}

The Siilinjärvi apatite sample represents a typical concentrate obtained in the Siilinjärvi Plant by flotation of apatite rock; the Sokli apatite samples were obtained by experimental enrichment of primary (Sample 1) and weathered (Sample 2) apatite rock. For comparison, data on commercial Kola and Kovdor apatites were also included in the study. The calculated content of apatite in the samples is in the range of $83-94 \%$. The remaining part of accompanying minerals in amounts $6-17 \%$ is represented mainly by calcite, dolomite, forsterite, phlogopite, and quartz (Table 1).

The chemical composition of the apatite samples is presented in Table 1 together with some other characteristics. P was determined spectroscopically as phosphomolybdate yellow complex, Ca by titration with $\mathrm{MnO}_{4}^{-}, \mathrm{Mg}$ by AAS, $\mathrm{F}$ by an ion-selective electrode from solution obtained by hydrothermal destruction of the sample and subsequent absorption of evolved HF into water, and $\mathrm{CO}_{2}$ by gravimetric analysis.

The FTIR spectra of apatites were recorded with a Nicolet ZDX FTIR spectrophotometer. The samples were pressed into $\mathrm{KBr}$ pellets (5 or $1 \mathrm{mg}$ of sample per $300 \mathrm{mg} \mathrm{KBr}$ ) under vacuum at a pressure of $0.1 \mathrm{~Pa}$. An analysis of the line shape of the OH bands in the FTIR spectra was performed by means of the Peak Fitting Program (PFP) "Galactic" ("Galactic peaksolve" 1995). Before the fitting procedure was applied the experimental 
data were smoothed by the Savitsky-Golay algorithm which convolutes a polynomial with the experimental spectrum.

The x-ray diffraction (XRD) analysis was carried out with a DRON-4 Diffractometer using $\mathrm{Cu}$ $\mathrm{K}_{\alpha}$ radiation at $40 \mathrm{kV}, 20 \mathrm{~mA}$. The samples were scanned in the range of $8-60^{\circ} 2 \theta$ with a step size of $0.04^{\circ}$.

\section{ANALYSIS AND DISCUSSION}

The chemical analyses show that, in their fluorine content, the Finnish apatites lie between the Kola and Kovdor apatites. The content of fluorine in the Siilinjärvi apatite is substantially higher (1.48 atoms/mole) in comparison with the Sokli apatites (1.01 and 1.04 atoms/mole). The entering of $\mathrm{CO}_{3}{ }^{2-}$ ions into the apatite structure, particularly that of the weathered sample of Sokli, was assumed. This was confirmed by the FTIR analysis.

The XRD patterns of the apatites show slight shifts in peak positions and intensities in comparison with the fluorapatite spectrum (ICDD PDF2 Card No 15-876). The apatite mineral of the weathered Sokli apatite was identified by card No 21-145 as carbonatefluorapatite; in the other samples as fluorhydroxycarbonateapatite (card No 31267). The unit cell parameter $a_{0}$ varies from 9.384 to $9.408 \AA$ and depends on the substitutions $\left(\mathrm{OH}^{-}\right.$ for $\mathrm{F}^{-}, \mathrm{CO}_{3}{ }^{2-}$ for $\mathrm{PO}_{4}^{3-}$ or $\mathrm{OH}^{-}$and others) and the differences of the ion positions in the apatite structure, specified more thoroughly by means of IR spectra. The main accompanying minerals in the apatite samples identified by XRD analysis are presented in Table 1.

In the IR absorption spectra of the samples the typical bands for apatite of $\mathrm{PO}_{4}{ }^{3-}$, asymmetric deformation $v_{4}$ at 601 and $570 \mathrm{~cm}^{-1}$, symmetric valence $v_{1}$ oscillation at $963 \mathrm{~cm}^{-1}$ and asymmetric valence $v_{3}$ oscillations at 1093 and $1042 \mathrm{~cm}^{-1}$ are represented (Fig. 1). The bands belonging to the $\mathrm{OH}$-ions on the hexagonal axis of the crystal (Figs. $2 \mathrm{a}$ and 3), to $\mathrm{CO}_{3}{ }^{2-}$ groups in the $\mathrm{PO}_{4}{ }^{3-}$ position or in the hexagonal axis (Fig. 4), and probably to $\mathrm{P}-\mathrm{O}-\mathrm{P}$ bands, are also revealed.

In the domain of the $\mathrm{OH}$ stretching modes of the interval at $3500-3600 \mathrm{~cm}^{-1}$ two bands can be seen. Decomposition of the $\mathrm{OH}$ bands by PFP "Galactic" and the residual trace are presented in Fig. 2b, and the results of the analysis in Table 2.

The most intensive $\mathrm{OH}$ stretching mode in the IR spectrum of the Kola fluorapatite is located at $3536 \mathrm{~cm}^{-1}$. This band belongs to the $\mathrm{OH}$ stretching mode in the hydrogen bond F...OH...F. The Kovdor apatite, in which the fluorine content is the lowest, shows three intensive bands at 3568,3547 and $3534 \mathrm{~cm}^{-1}$ and a weak band at $3584 \mathrm{~cm}^{-1}$. The intensive bands can be attributed to two nonequivalent hydrogen bonds: $\mathrm{OH} \cdots \mathrm{F}$ $\left(3534 \mathrm{~cm}^{-1}\right)$ and $\mathrm{OH} \cdots \mathrm{F} \cdots \mathrm{HO}\left(3547 \mathrm{~cm}^{-1}\right)$ (Freund \& Knobel 1977), and the band at $3568 \mathrm{~cm}^{-1}$ probably to the hydrogen bond OH...O (Elliott 1994). The most intensive $\mathrm{OH}$ stretching mode in the spectra of the Siilinjärvi and Sokli apatites is at about $3537 \mathrm{~cm}^{-1}$. The other bands, excluding the band at $3552 \mathrm{~cm}^{-1}$ absent from the Kola apatite spectrum, also coincide, but the ratios of their intensities differ. In the spectrum of the Sokli apatite, which contains more $\mathrm{OH}$ ions, these bands are more intensive. The differences in the apatite spectra may also be due to vacancies and the possible rotational and translational disorder in the structure.

The data on the $\mathrm{OH}$ stretching mode are in agreement with the data on the liberation mode of the $\mathrm{OH}$ ions (Fig. 3). According to Freund and Knobel (1977), the bands at 745, 671 and $638 \mathrm{~cm}^{-1}$ belong to the vibrations of $\mathrm{OH}^{-}$-ions of the $\mathrm{OH} \cdots \mathrm{F}$ and in $\mathrm{OH} \cdots \mathrm{O}$ bonds, respectively. The bands at 671 and $638 \mathrm{~cm}^{-1}$ are clearly established only in the spectrum of the Kovdor apatite. In the spectra of the Sokli and Siilinjärvi apatites only weak bands at $673 \mathrm{~cm}^{-1}$ are seen. Bands at about $745 \mathrm{~cm}^{-1}$ were distinctly fixed for the Kola and Siilinjärvi apatites which contain more fluorine. The band at $720 \mathrm{~cm}^{-1}$ is clearly observed only in the case of the Kovdor apatite. In the spectra of the Sokli apatites a band at $730 \mathrm{~cm}^{-1}$ was fixed.

According to Knubovets (1993), the bands in the domain of $745-720 \mathrm{~cm}^{-1}$ in apatite spectra could also be attributed to symmetric valence oscillations of the P-O-P bridge bonds, formed by condensation of the $\mathrm{PO}_{4}{ }^{3-}$ tetrahedron. 


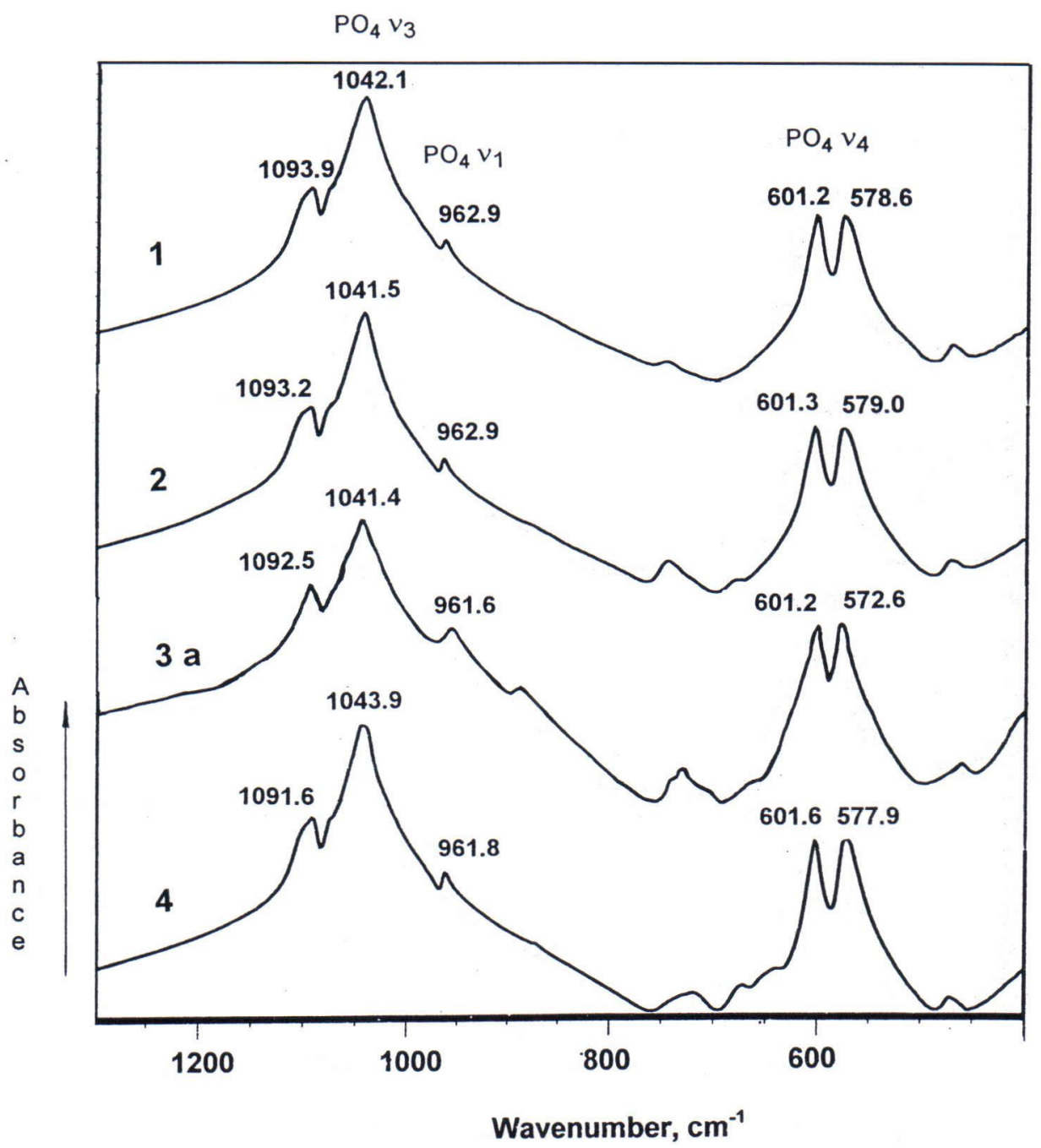

Fig. 1. IR spectra of the apatites in the domain of $\mathrm{PO}_{4}^{3-}$ vibrations: 1-Kola; 2- Siilinjärvi; 3 a- Sokli (primary); 4- Kovdor.

Due to their low content, identification of $\mathrm{CO}_{3}{ }^{2-}$ ions in the apatite structure and their location in either $\mathrm{A}$ or $\mathrm{B}$ position (substitution of $\mathrm{CO}_{3}{ }^{2-}$ for $\mathrm{OH}^{-}$or $\mathrm{PO}_{4}{ }^{3-}$ ions, respectively) is complicated. In the domain of $\mathrm{CO}_{3}{ }^{2-}$ ion oscillations there are probably at least 6 bands: at $1515,1506,1465-1471$, 1452-1458, 1426-1434, and 1418-1423 cm-1 (Fig. 4). Attributing each band to a certain type of carbonateapatite is impossible as the frequencies of oscillations also depend on other substitutions and, in the case of mixed AB-type apatites, new bands are added (Beshah et al. 1990). By nuclear magnetic resonance (NMR) studies, five structurally nonequivalent states of the $\mathrm{CO}_{3}{ }^{2-}$ ion in the carbonateapatites have been established (Beshah et al. 1990). Nevertheless, when comparing the data obtained for $\mathrm{CO}_{3}{ }^{2-} \mathrm{v}_{3}$ oscillations in the carbonateapatites by Rey et al. (1989), it can be concluded that all the apatite samples studied here contain $\mathrm{CO}_{3}{ }^{2-}$ ions in $\mathrm{A}$ and $\mathrm{B}$ positions, but in dif- 
a)

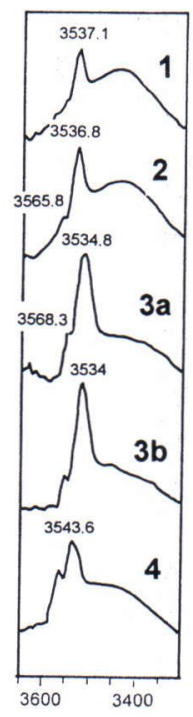

Wavenumber, $\mathrm{cm}^{-1}$ b)

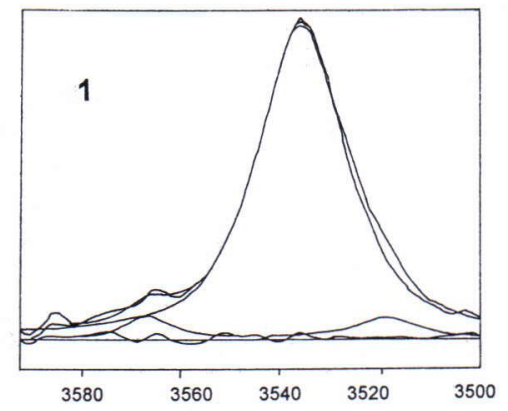

Wavenumber, $\mathrm{cm}^{-1}$

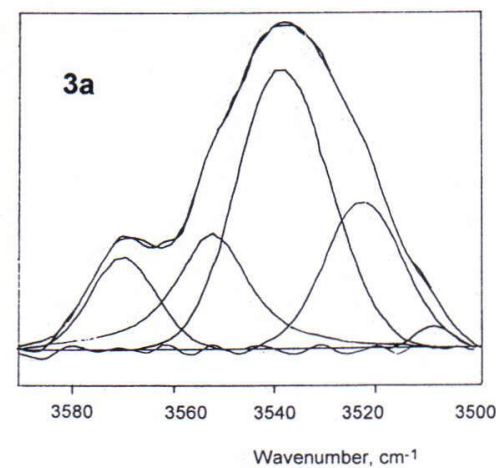

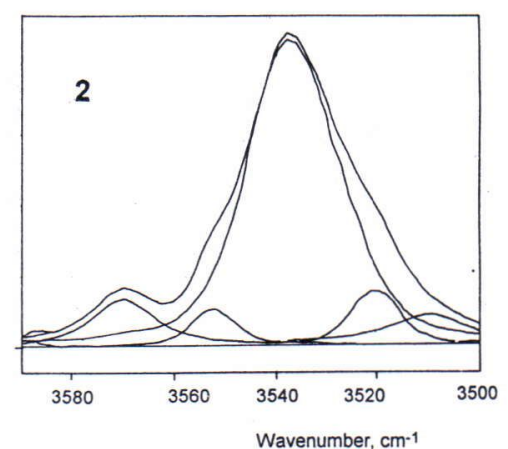

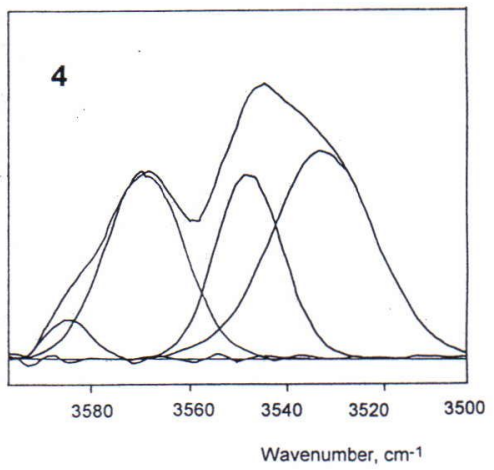

Fig. 2. (a) $\mathrm{OH}$ and $\mathrm{H}_{2} \mathrm{O}$ bands in the IR spectra at 3300 - $3600 \mathrm{~cm}^{-1}$ of apatites: 1- Kola; 2- Siilinjärvi; 3- Sokli a) primary, $b$ ) weathered; 4-Kovdor. (b) Splitting of the $\mathrm{OH}$ stretching mode and the residual trace after line shape analysis in the FTIR spectra of apatites.

ferent amounts and ratios. The same result was obtained by polarized infrared spectroscopy of synthetic apatites (Suetsugu et al. 1998).

It is necessary to mention that the analysis of the apatite spectra obtained may be complicated because of the presence of admixtures (like silicates, and incompletely separated carbonates), in particular in the domains of the spectra where the bands are close to each other.

\section{SUMMARY}

The use of FTIR spectroscopy improved with computerized data processing by means of the Peak Fitting Program "Galactic" which gives complementary information about structural properties of natural apatites of different ori- gin and deposits. In particular, this is demonstrated on the basis of $\mathrm{OH}$-group stretching mode vibrations of magmatic fluorhydroxyapatites from the Siilinjärvi and Sokli deposits in Finland. For comparison apatites from the Kola and Kovdor deposits (northwestern Russia) were also studied.

In apatites rich in fluorine, F...OH...F and F...OH bonds dominate, while in the Kovdor apatite, the sample with the lowest fluorine content, the highest band intensity corresponds to $\mathrm{OH}$...F...OH bond vibrations. Differences in the amount and position of $\mathrm{CO}_{3}^{2-}$ ions incorporated into the apatite structure are also shown.

ACKNOWLEDGEMENTS: The authors thank Dr. $H$. Vartiainen for providing the Sokli apatite samples. 


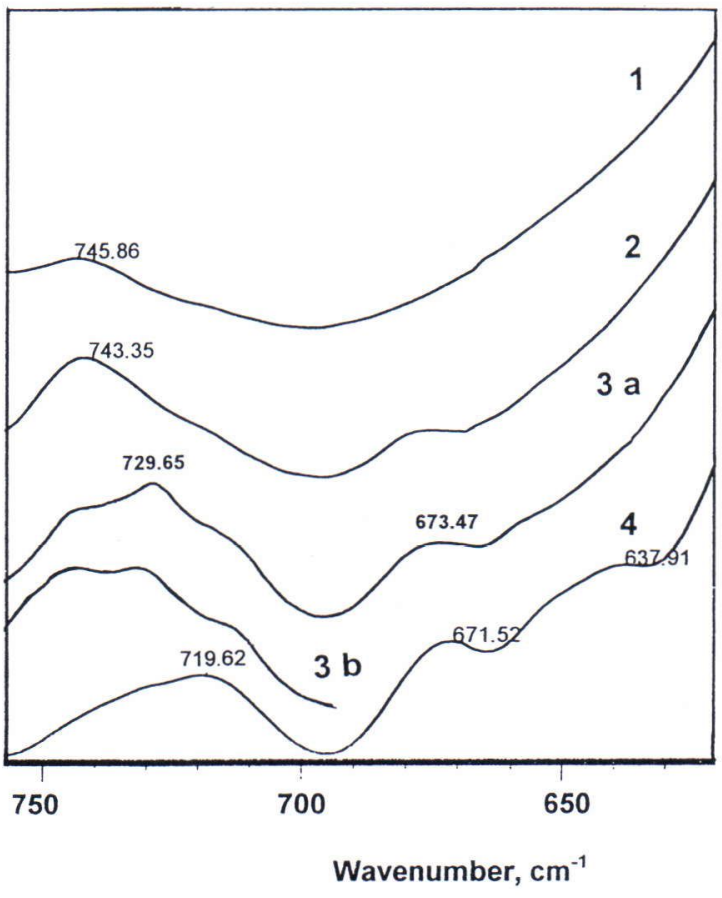

Fig. 3. The liberational vibrations of the $\mathrm{OH}$ ions at $620-760 \mathrm{~cm}^{-1}$. Numbers as in Fig. $2 a$.

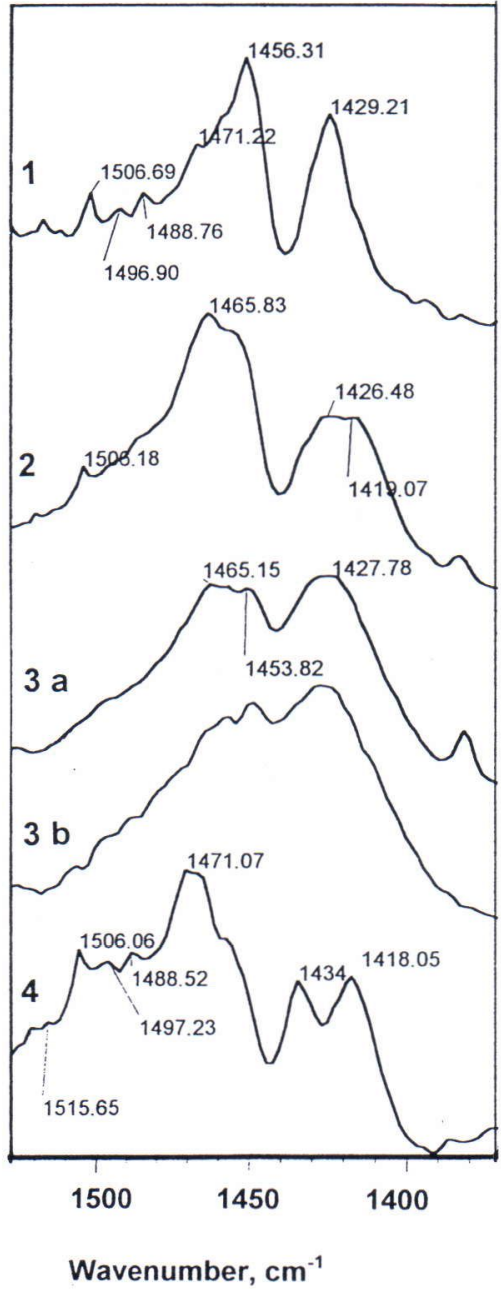

Fig. 4. $\mathrm{CO}_{3}{ }^{2-}$ bands in the IR spectra of apatites at 1370-1530 $\mathrm{cm}^{-1}$. Numbers as in Fig. $2 a$.

Table 2. OH stretching mode in the FTIR spectra of magmatic apatites according to the data of Peak Fitting "Galactic".

\begin{tabular}{|c|c|c|c|c|c|c|c|c|}
\hline \multicolumn{2}{|c|}{ Siilinjärvi } & \multicolumn{2}{|c|}{ Sokli } & \multicolumn{2}{|c|}{ Kola } & \multicolumn{2}{|c|}{ Kovdor } & \multirow[t]{2}{*}{ Bond } \\
\hline $\mathrm{cm}^{-1}$ & height & $\mathrm{cm}^{-1}$ & height & $\mathrm{cm}^{-1}$ & height & $\mathrm{cm}^{-1}$ & height & \\
\hline & & & & 3587 & 002 & 3584 & 001 & \\
\hline 3570 & 009 & 3570 & 020 & 3567 & 003 & 3568 & 067 & $\mathrm{OH}-\mathrm{O}$ ? \\
\hline 3552 & 007 & 3551 & 020 & & & 3547 & 067 & OH...F...OH \\
\hline 3537 & 080 & 3536 & 050 & 3536 & 040 & 3534 & 075 & F...OH...F \\
\hline \multirow[t]{2}{*}{3521} & 020 & 3520 & 020 & 3520 & 003 & & & F...OH...(F) \\
\hline & & 3508 & 004 & & & & & $\mathrm{OH} . . . \mathrm{F}-\mathrm{CO}_{3}$ \\
\hline
\end{tabular}




\section{REFERENCES}

Beshah, K., Rey, C., Glimber, M.J., Shimizu, M. \& Griffin, R.C. 1990. Solid state carbon-13 and proton NMR studies of carbonate-containing calcium phosphates and enamel. Journal of Solid State Chemistry 84, 71-81.

Elliott, J. 1994. Structure and Chemistry of the Apatites and Other Calcium Orthophosphates. Amsterdam: Elsevier. 389 p.

Freund, F. \& Knobel, R.M. 1977. Distribution of fluorine in hydroxyapatite studied by infrared spectroscopy. Journal of the Chemical Society, Dalton Transactions 11, 1136-1140.

Gadaleta, S.J., Paschalis, P.E., Betts, F., Mendelsohn, R. \& Boskey, A.L. 1996. Fourier transformation infrared spectroscopy of the solution-mediated conversion of amorphous calcium phosphate to hydroxyapatite: New correlations between X-ray diffraction and infrared data. Calcified Tissue International 58, 9-16.

"Galactic peaksolve" 1995. Peak fitting for Windows, User's guide. Galactic Industries Corporation. 225 p.

Knubovets, R. 1993. Structural mineralogy and properties of natural phosphates. Reviews in Chemical Engineering 9, 161-216.

Penel, G., Leroy, G., Rey, C., Sombrat, B., Huvenne, J.P. \& Bres, E. 1997. Infrared and Raman microspectrometry study of fluor-fluor-hydroxy and hydroxy-apatite powders. Journal of Materials Science: Materials in Medicine 8, 271-276.

Puustinen, K. 1971. Geology of the Siilinjärvi carbonatite complex, Eastern Finland. Bulletin de la Commision Géologique de Finlande 249. 43 p.
Regnier, P., Lasaga, A.C., Berner, R.A., Han, O.H. \& Zilm, K.W. 1994. Mechanism of $\mathrm{CO}_{3}{ }^{2-}$ substitution in carbonate-fluorapatite: Evidence from FTIR spectroscopy, ${ }^{13} \mathrm{C}$ NMR, and quantum mechanical calculations. American Mineralogist 79, 809-818.

Rehman, I. \& Bonfield, W. 1997. Characterization of hydroxyapatite and carbonated apatite by photo acoustic FTIR spectroscopy. Journal of Materials Science: Materials in Medicine 8, $1-4$.

Rey C., Collins B., Goehl T., Dickson, I.R. \& Glimcher, M.J. 1989. The carbonate environment in minerals. Calsified Tissue International 45, 157-164.

Silverman, S.R., Fuyat, R.K., \& Weiser, J.D. 1952. Quantitative determination of calcite associated with carbonate-bearing apatites. American Mineralogist 37, 211222.

Suetsugu, Y., Shimoya, I. \& Takana, J. 1998. Configuration of carbonate ions in apatite structure determined by polarized infrared spectroscopy. Journal of the American Ceramic Society 81, 746-748.

Vartiainen, H. 1980. The petrography, mineralogy and petrochemistry of the Sokli carbonatite massif, northern Finland. Geological Society of Finland, Bulletin 313. $126 \mathrm{p}$.

Veiderma, M. \& Knubovets, R. 1991. Kiruna apatite. Scandinavian Journal of Metallurgy 20, 329-330.

Veiderma, M., Knubovets, R. \& Tõnsuaadu, K. 1996. Fluorhydroxyapatites of Northern Europe and their thermal transformations. Phosphorus, Sulfur and Silicon 109-110, 43-46. 